\title{
Media Puzzle untuk Mengenal Bentuk Geometri
}

\author{
Ratna Pangastuti ${ }^{1}$
}

Received: 17052019 / Accepted: 25052019 / Published online: 15062019

(c) 2019 Early Chilhood Islamic Education Study Program

Abstract: Learning media are all things that can be used to channel learning materials so that they can stimulate the attention, interests, thoughts and feelings of students (students) in learning activities to achieve certain learning goals. Learning media is a tool or other material that provides a complete form of information and can support the teaching and learning process. Learning in the introduction of geometric shapes in early childhood really requires appropriate learning strategies and media, so to maximize the child's ability to introduce geometric shapes can use puzzle media. Compiling geometric shapes puzzles can improve cognitive for children. Cognitive skills (cognitive skills) associated with the ability to learn and solve problems in children. Moreover, it can improve social skills for children. By using the content analysis method and the study documentation, this research tries to describe the puzzle media to introduce geometric shapes to early childhood.

Keywords: Puzzle, Geometric Shape

\begin{abstract}
Abstrak: Media pembelajaran adalah segala sesuatu yang dapat digunakan untuk menyalurkan bahan pembelajaran sehingga dapat merangsang perhatian, minat, pikiran dan perasaan pebelajar (siswa) dalam kegiatan belajar untuk mencapai tujuan pembelajaran tertentu. Media pembelajaran adalah alat atau materi lain yang menyajikan bentuk informasi secara lengkap dan dapat menunjang proses belajar mengajar. Pembelajaran dalam pengenalan bentuk geometri pada anak usia dini sangat memerlukan strategi pembelajaran dan media yang tepat, maka untuk memaksimalkan kemampuan anak dalam mengenalkan bentuk geometri dapat menggunakan media puzzle. Menyusun puzzle bentuk geometri ini dapat meningkatkan kognitif bagi anak. Keterampilan kognitif (cognitive skill) berkaitan dengan kemampuan dalam belajar anak dan memecahkan masalah. Selain itu dapat meningkatkan keterampilan sosial bagi anak. Dengan menggunakan metode analisis konten dan telaah dokmentasi penelitian ini berusaha mendeskripsikan tentang media puzzle untuk mengenalkan bentuk geometri kepada anak usia dini.
\end{abstract}

Kata Kunci: Puzzle, Bentuk Geometri 


\section{PENDAHULUAN}

Anak usia dini adalah sosok individu yang sedang menjalani suatu proses perkembangan dengan pesat dan fundamental bagi kehidupan selanjutnya. Proses pembelajaran sebagai bentuk yang diberikan pada anak harus memperhatikan karakteristik yang dimiliki setiap tahapan perkembangan anak. Anak memiliki karakteristik tertentu yang khas dan tidak sama dengan orang dewasa, mereka selalu aktif, dinamis, antusias dan ingin tahu terhadap yang dilihat, didengar, dirasakan, mereka seolah-olah tidak pernah berhenti bereksplorasi dan belajar.

Undang-undang nomor 20 tahun 2003 tentang sistem Pendidikan Nasional Pasal 1 angka 14 menyatakan bahwa Pendidikan Anak Usia Dini (PAUD) adalah suatu upaya pembinaan yang ditujukan kepada anak sejak lahir sampai dengan usia enam tahun yang dilakukan melalui pemberian rangsangan pendidikan untuk membantu pertumbuhan dan perkembangan jasmani dan rohani agar anak memiliki kesiapan dalam memasuki pendidikan lebih lanjut (Kemendiknas, 2003)

Rentang usia lahir sampai enam tahun anak mengalami masa keemasan (the golden age) yang merupakan masa dimana anak mulai peka/sensitif untuk menerima berbagai rangsangan. Masa peka pada masing-masing anak berbeda, seiring dengan laju pertumbuhan dan perkembangan anak secara individual. Masa ini juga merupakan masa peletak dasar pertama untuk mengembangkan kemampuan kognitif, bahasa, gerakmotorik, dan sosioemosional pada anak usia dini (Sujiono, 2004). ${ }^{1}$

Dengan adanya golden age tersebut hendaknya menjadi acuan bagi orang tua untuk menyekolahkan anaknya sejak usia dini. Di Taman Kanak-Kanak (TK) setiap anak akan dibantu mengembangkan berbagai potensi baik psikis maupun fisik untuk siap memasuki pendidikan dasar (Depdiknas: 2010.4).

Di Taman Kanak - kanak dan lembaga pendidikan yang sejenis lainnya pengembangan kognitif dikenal juga dengan istilah pengembangan daya pikir. Pengembangan kognitif dimaksudkan agar anak mampu melakukan eksplorasi terhadap dunia sekitar melalui pencaindranya, sehingga tujuan pengembangan kognitif diarahkan pada pengembangan kemampuan auditori, visual, taktil, kinestetik, aritmatika, geometri dan sains permulaan.

Orang tua sering kali melihat keberhasilan dari perkembangan kognitif, diantaranya mengenal konsep bentuk, warna, ukuran, dan pola. Dengan belajar mengenal bentuk geometri dapat mendorong seseorang bisa berfikir secara logis karena dengan mempelajari geometri seseorang akan belajar berfikir dan memecahkan masalah secara sistematis. Bentuk geometri merupakan potongan kayu yang memiliki macam-macam bentuk serta tidak hanya terbuat dari kayu melainkan beragam bahan yang digunakan misalnya karton, busa, karet.

Lingkup perkembangan kognitif anak sesuai dengan usianya. Tingkat pencapaian perkembangan kognitif anak, kelompok usia $2-\leq 4$ tahun dapat mengenal tiga macam bentuk geometri yaitu lingkaran, persegi, dan segitiga. Lingkaran adalah kurva tertutup sederhana di mana titik-titik pada kurva itu bejarak sama terhadap sebuah titik (pusat lingkaran). Persegi empat adalah segi empat yang keempat sudutnya siki-siku dan sama panjang. Segitiga adalah sebuah bangun bidang datar yang dibentuk dengan cara menghubungkan tiga buah titik yang tidak segaris .

Dalam proses pengenalan bentuk geometri disekolah guru dapat menggunakan berbagai media pembelajaran. Sehingga anak mudah memahami apa yang diajarkan guru selama proses pembelajaran berlangsung. Tidak hanya media yang digunakan untuk 
mempermudah anak menerima pembelajaran, guru juga menerapkan metode pembelajaran yang menarik sehingga anak tertarik untuk belajar.

\section{METODE}

Penelitian ini berbentuk penelitian kepustakaan (library research). Dalam penelitian ini, peneliti menggunakan metode analisis deskriptif. Analisis deskriptif adalah suatu metode dengan jalan mengumpulkan data, menyusun atau mengklasifikasi, menganalisis, dan menginterpretasikannya (Natsir, 1999: 63) dengan tahapan-tahapan sebagai berikut (Natsir, 1999: 73) - Mengumpulkan sumber referensi yang berkaitan dengan masalah yang diteliti serta mempelajarinya. - Setelah sumber referensi terkumpul diklasifikasikan data yang terdapat pada obyek penelitian dengan landasan teori yang telah diperoleh dari sumber-sumber referensi. • Mempelajari tentang media puzzle untuk memperoleh data yang dibutuhkan kemudian diklasifikasikan sesuai dengan sifat yang diperoleh - Kemudian dilakukan proses analisa mengenai topik permasalahan yang diteliti mengenai media puzzle untuk mengenal bentuk geometri.

Teknik pengumpulan data yang digunakan dalam penelitian ini adalah studi kepustakaan, yaitu dengan mengumpulkan data-data yang berkaitan dengan pembahasan kemudian dianalisis berdasarkan kajian yang ada dalam literatur terkait media puzzle untuk mengenal bentuk geometri. Dalam penelitian ini adalah analisis isi (content analysis), yaitu penelitian yang bersifat pembahasan mendalam terhadap isi suatu informasi tertulis atau tercetak dalam media massa (Afifuddin \& Beni, 2009: 145).

\section{HASIL PENELITIAN DAN ANALISIS Pengertian Media}

Media berasal dari kata latin "medium" yang berarti "di antara", suatu istilah yang menunjukkan segala sesuatu yang membawa informasi antara sumber dan penerima. Menyatakan bahwa media pembelajaran mencakup semua sumber yang diperlukan untuk melakukan komunikasi dengan anak, dapat berupa perangkat keras, seperti komputer, televisi, projektor, dan perangkat lunak yang digunakan dalam perangkat-perangkat keras tersebut.

Dengan demikian, media pembelajaran adalah segala sesuatu yang dapat digunakan untuk menyalurkan bahan pembelajaran sehingga dapat merangsang perhatian, minat, pikiran dan perasaan pebelajar (siswa) dalam kegiatan belajar untuk mencapai tujuan pembelajaran tertentu. Media pembelajaran adalah alat atau materi lain yang menyajikan bentuk informasi secara lengkap dan dapat menunjang proses belajar mengajar.

\section{Pengertian Puzzle}

Puzzle merupakan model teka-teki dengan bentuk menyusun potongan-potongan gambar menjadi kesatuan gambar yang utuh. Selain itu puzzle adalah permainan yang sangat popular, terutama dikalangan anak-anak. Pada umumnya gambar yang digunakan adalah gambar kesuka anak-anak seperti kartun, angka, buah, mobil, hewan, dan lain sebagainya.

Puzzle adalah permainan yang menarik bagi anak. Sebab, pada dasarnya ia menyukai bentuk gambar dan warna yang menarik, pada awalnya ia mungkin mencoba menyusun gambar puzzle tanpa petunjuk (Jatmika, 2012). ${ }^{5}$ Dengan sedikit arahan dan contoh, maka dia dapat mengembangkan kemampuan sosial (kerja sama) dengan cara 
mencoba menyusun bentuk, warna atau logika bersama teman-temannya. Sedangkan menurut Kamus Besar Bahasa Inggris-Indonesia "puzzle berarti memecahkan teka-teki".

Maka yang dimaksud puzzle adalah sebuah permaian atau media yang pada umumnya berupa teka-teki potongan bentuk yang nantinya akan dirangkai menjadi sebuah kesatuan yang utuh.

\section{Aturan Permainan Puzzle Bagi AUD}

Dalam permainan puzzle, ada beberapa aturan yang harus dipenuhi adalah sebagai berikut :

a. Mengumpulkan berbagai jenis puzzle. Kemudian, tuntunlah anak dengan memberikan kebebasan kepadanya untuk memilih gambar dan jenis puzzle yang disukai.

b. Setelah anak-anak memilih jenis puzzle sesuai kesukaannya, tuntunlah mereka dengan menanyakan bentuk dan gambar yang mereka pilih. Misalnya, puzzle geometri. Rangsang anak sambil berdilog.

c. Setelah itu, anak memasang dan mencocokkan kembali satu per satu kepingan hingga menjadi suatu bentuk utuh.

d. Tantanglah anak untuk melakukannya lebih cepat dan lebih cepat lagi.

e. Terakhir, ucapkan terimakasih dan berikanlah pujian pada anak.

Selain aturan bermain puzzle yang dijelaskan diatas secara umum, terdapat juga aturan bermain puzzle yang dilakukan secara umum, terdapat juga aturan bermain puzzle yang dilakukan secara bersama-sama atau bisa dikatakan dikerjakan secara berkelompok adalah :

a. Peserta dibagi dalam kelompok yang terdiri dari 5-6 orang, salah satunya menjadi pengamat (ditentukan sendiri oleh masing-masing kelompok).Tiap peserta dalam kelompok memperoleh satu gambar yang sudah dipotong-potong kecuali pengamat), yang dijadikan satu dalam satu wadah dengan potongan-potongan peserta lain.

b. Tugas masing-masing peserta menyusun kembali potongan-potongan gambar yang utuh, dengan ketentuan:

1) Jika memperoleh potongan gambar yang tidak diperlukan atau tidak sesuai, peserta harus segera mengembalikan ke dalam wadah agar peserta lain dapat mengambil jika cocok dengan gambar yang dimiliki.

2) Tidak boleh meminta atau mengambil dari peserta lain, tetapi hanya boleh mengambil potongan gambar dari wadah.

3) Tidak boleh saling berbicara, berkomunikasi dengan isyarat ataupun campur tangan dalam pekerjaan peserta lain.

Tugas pengamat dalam setiap kelompok mengamati dan mencatat apa yang terjadi pada kelompoknya selama bermain berlangsung dengan memperhatikan hal-hal berikut :

a) Adakah peserta yang melanggar peraturan?

b) Peraturan mana yang dilanggar?

c) Adakah peserta yang menumpuk banyak potongan gambar dan tidak ingin mengembalikan ke wadah/meja?

Ulangi permainan ini dengan ketentuan, peserta boleh berkomunikasi dan saling membantu dalam kelompoknya.

Dari beberapa pendapat tersebut dapat di simpulkan bahwa aturan bermain puzzle adalah:

1) Peserta dibagi menjadi kelompok, tiap kelompok terdapat 2 anak.

2) Tiap kelompok mendapat potongan-potongan puzzle.

3) Tiap kelompok harus menyelesaikan potongan-potongan bentuk tersebut menjadi utuh. 
4) Kelompok yang selesai terlebih dahulu akan mendapat ucapan selamat dan terimakasi.

\section{Manfaat Permainan Puzzle Bagi AUD}

Didalam permainan ada manfaat yang dapat kita ambil dan dibawah ini menjelaskan manfaat puzzle adalah sebagai berikut:

a. Merangsang motorik halus anak saat menyusun potongan gambar permainan ini juga dapat melatih anak berfikir, yakni mulai melihat potongan bentuk puzzle, memahami bentuknya, dan berupaya menata kembali bentuk tersebut setelah diacak-acak. Aktivitas ini juga mengasah kesabaran anak dalam mencari pemecahan masalah.

b. Melatih kesabaran. Puzzle juga melatih kesabaran anak dalam menyelesaikan suatu tantangan.

c. Meningkatkan kemampuan berfikir dan membuat anak belajar berkonsentrasi. Saat bermain puzzle, anak akan melatih sel-sel otaknya untuk mengembangkan kemampuan berfikirnya dan berkonsentrasi dalam menyelesaikan potongan-potongan kepingan gambar tersebut.

d. Melatih koordinasi tangan dan mata. Puzzle dapat melatih koordinasi tangan dan mata anak untuk mencocokkan kepingan-kepingan puzzle dan menyusunnya menjadi satu gambar. Puzzle juga membantu anak mengenal dan menghafal bentuk.

e. Meningkatkan keterampilan kognitif. Keterampilan kognitif (cognitive skill) berkaitan dengan kemampuan dalam belajar dan memecahkan masalah. Puzzle adalah permainan yang menarik bagi anak balita karena ia pada dasarnya menyukai bentuk gambar dan warna yang menarik. Dengan bermain puzzle, anak akan mencoba memecahkan masalah, yaitu menyusun gambar.

f. Meningkatkan keterampilan sosial. Keterampilan sosial barkaitan dengan kemampuan berinteraksi dengan orang lain. Puzzle dapat dimainkan secara perorangan maupun berkelompok. Permainan yang dilakukan oleh anak-anak secara berkelompok akan meningkatkan interaksi sosial anak. Dalam kelompok, anak akan saling menghargai, membantu, dan berdiskusi satu sama lain.

Dari penjelasan di atas, dapat ditarik kesimpulan bahwa puzzle merupakan alat permainan edukatif berupa teka-teki atau mainan bongkar pasang yang dapat di berikan kepada anak mulai dari anak balita sampai anak belasan tahun. Puzzle dapat mengembangkan kemampuan kognitif, kemampuan motorik, melatih konsentrasi, dan melatih sosial emosional pada anak.

\section{Tahapan Pembuatan Media Puzzle Geometri}

Media yang digunakan dalam pengembangan kognitif anak TK pada dasarnya merupakan media yang tidak berbahaya, menyenangkan, dan bisa membantu guru menghubungkan satu hal dengan hal lainnya. Prinsip-prinsip pembuatan media, keberhasilannya ditunjang dengan unsur-unsur visual seperti garis, tekstur, dan ruang.

a. Garis, dalam media visual dapat menghubungkan unsur-unsur bersama dan akan membimbing pemirsa untuk mempelajari media tersebut dalam suatu ukuran tertentu.

b. Bentuk yang aneh (tidak biasa) dapat menimbulkan suatu perhatian khusus pada suatu yang divisualkan.

c. Ruang terbuka diiringi dengan unsur-unsur visual dan kata-kata akan mencegah rasa berjejal dalam suatu media visual. 
d. Tekstur adalah unsur visual yang disajikan sebagai pengganti sentuhan rasa tertentu dan dapat juga dipakai sebagai pengganti warna, memberikan penekanan, pemisahan atau untuk meninggkatkan kesatuan.

e. Warna merupakan unsur tambahan yang terpenting dalam media visual, tetapi harus digunakan secara hati-hati untuk memperoleh pengaruh terbaik.

Dengan adanya kriteria pembuatan media diatas maka alat dan bahan untuk membuat media puzzle geometri adalah kayu, papan, gergaji, pilox, penggaris, spidol dan amplas.

Cara pembuatan media puzzle geometri adalah :

a) Balok kayu panjang dipotong kecil dengan ukuran $5 \mathrm{~cm}$ lalu dibentuk persegi, lingkaran dan segitiga.

b) Persegi, segitiga dan lingkaran yang sudah jadi diamplas hingga halus.

c) Setelah halus kepingan geometri tersebut dicat dengan menggunakan pilox hingga merata.

d) Sambil menunggu kepingan geometri kering, siapkan papan untuk membuat alas puzzle.

e) Gergaji alas puzzle sesuai dengan ukuran yang diperlukan.

f) Setelah alas puzzle dihaluskan dengan amplas, lalu dicat menggunakan pilox.

g) Setelah kering media puzzle geometri siap untuk dimainkan.

\subsection{Bentuk Geometri}

Geometri merupakan potongan kayu yang memiliki macam-macam bentuk serta tidak hanya terbuat dari kayu melainkan beragam bahan yang digunakan misalnya karton, busa, karet.

Kemampuan geometri berhubungan dengan konsep bentuk dan ukuran. mengemukakan bahwa geometri adalah :

1) Cabang matematika yang mempelajari pola-pola visual.

2) Cabang matematika yang menghubungkan matematika dengan dunia fisik atau dunia nyata.

3) Suatu cara penyajian fenomena yang tidak bersifat fisik.

4) Suatu contoh sistem matematika.

Belajar geometri mendorong seseorang bisa berfikir secara logis karena dengan mempelajari geometri seseorang akan belajar berfikir dan memecahkan masalah secara sistematis. Jadi geometri adalah cabang matematika yang mempelajari pengukuran dan bentuk.

\section{Contoh-Contoh Geometri Yang Di Kenal Anak TK}

Berikut contoh-contoh bentuk geometri yang dikenal anak TK menurut Shobirin (2008:2-5):

1) Segitiga

Segitiga adalah sebuah bangun bidang datar yang dibentuk dengan cara menghubungkan tiga buah titik yang tidak segaris. Di bawah ini adalah gambar dari bentuk segitiga :

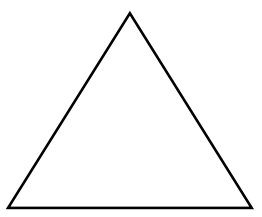

Gambar 2.2 Segitiga 
2) Lingkaran

Lingkaran adalah kurva tertutup sederhana dimana titik-titik pada kurva itu bejarak sama terhadap sebuah titik (pusat lingkaran). Berikut gambar lingkaranya:

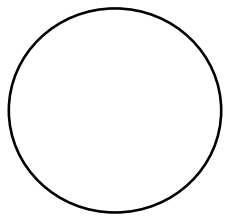

Gambar 2.3 Lingkaran

3) Segi empat

Segi empat adalah sebuah bangun datar yang dibentuk dengan cara menghubungkan empat buah titik yang tidak segaris. Macam-macam segi empat:

1) Persegi empat adalah segi empat yang keempat sudutnya siki-siku dan sama panjang. Berikut adalah gambar persegi:

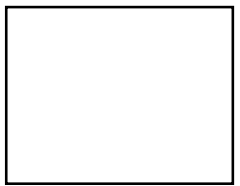

\section{Gambar 2.4 Persegi}

2) Persegi panjang adalah segi empat yang keempat sudut siku-siku dan sisi-sisi yang berhadapan saling sejajar dan sama panjang. Berikut gambar persegi panjang :

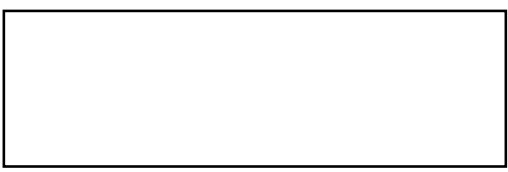

Gambar 2.5 Persegi Panjang

3) Jajar genjang adalah segi empat yang sepasang sisinya sejajar dan sama panjang. Berikut gambar jajar genjang :

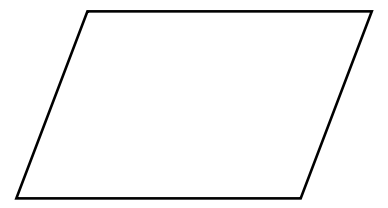

\section{Gambar 2.6 Jajar Genjang}

4) Belah ketupat adalah segi empat yang sisinya sama panjang, sisi-sisi yang saling berhadapan sejajar, dan perpotongan diagonalnya membentuk sudut siku-siku. Berikut adalah gambar belah ketupat:

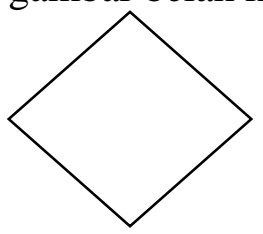

Gambar 2.7 Belah Keupat 
5) Layang - layang adalah segi empat dengan dua pasang sisi yang berdekatan sama panjang dan perpotongan diagonal membentuk sudut siku-siku. Berikut gabar layang-layang:

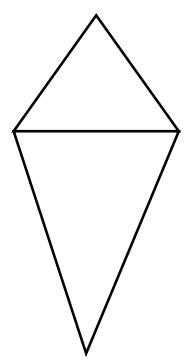

Gambar 2.8 Layang - layang

6) Trapesium adalah segi empat yang memiliki sepasang sisi yang berhadapan sejajar. Berikut gambar trapesium:

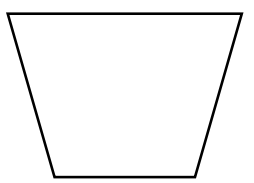

\section{Gambar 2.9 Trapesium}

\section{Kemampuan Geometri Pada Anak TK}

Kemampuan geometri berhubungan dengan pengembangan konsep bentuk dan ukuran. Adapun kemampuan yang akan dikembangkan, antara lain:

a. Memilih benda menurut warna, bentuk, dan ukurannya.

b. Mencocokkan benda menurut warna, bentuk, dan ukurannya.

c. Membandingkan benda menurut ukurannya besar, kecil, panjang, lebar, tinggi, rendah.

d. Mengukur benda secara sederhana.

e. Mengerti dan menggunakan bahasa ukuran, seperti besar-kecil, tinggi - rendah, panjang-pendek.

f. Menciptakan bentuk dari kepingan geometri.

g. Menyebut benda-benda yang ada di kelas sesuai dengan bentuk geometri

h. Mencontoh bentuk - bentuk geometri.

i. Menyebut, menunjukkan dan mengelompokkan segi empat.

j. Mengenal ukuran panjang, berat dan isi.

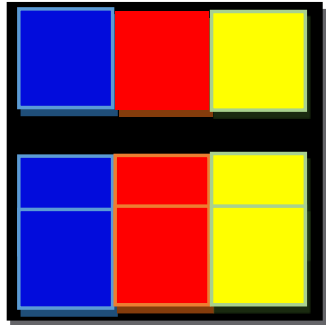

(a)

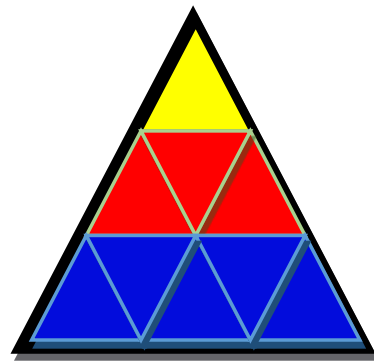

(b)

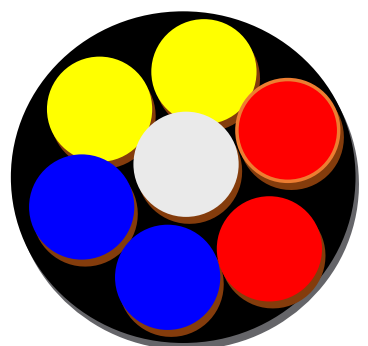

(c)

Gambar 2.10

Contoh Gambar Puzzle Bentuk Geometri 
Keterangan :

(a): Persegi adalah yang keempat sudutnya siku-siku dan sama panjang

(b): Segitiga adalah sebuah bangan bidang datar yang dibentuk dengan cara menghubungkan tiga buah titik yang tidak segaris.

(c): Lingkaran adalah kurva tertutup sederhana dimana titik-titik pada kurva itu berjarak sama terhadap sebuah titik (pusat lingkaran).

\section{Manfaat Geometri Bagi AUD}

Menurut Alexander dalam tulisannya "All About Unit Block Play" manfaat yang diperoleh anak melalui bermain geometri antara lain :

a. Pengembangan berhitung, mencakup simbolisasi dan penyajian, comparisons, penggolongan, konsep, directionalist, berurutan, pemikiran yang berbeda dan logika berfikir.

b. Pengembangan fisik, yang mencakup koordinasi, persepsi, visual, pengembangan motorik orientasi spasial/ruang, dan koordinasi motorik yang bagus.

c. Sosial emosional, mencakup pengembangan kompetensi/wewenang, kesuksesan harga diri, otonomi/kemandirian, inisiatif, pemasaran, kerjasama, negoisasi, kompromi, dan tanggung jawab

d. Kreatifitas, mencakup asosiasi, hubungan, pemecahan masalah, mencari solusi baru, dan eksplorasi sensori.

e. Matematika, mencakup area, ukuran, order, ruang, bentuk, angka,

f. Pemetaan, pola, perkiraan, hubungan antar satuan dan penjumlahan/penambahan.

g. Keaksaraan, mencakup pemberian nama, kosakata, menceritakan kembali, mengarang cerita, membuat dan menggunakan lambang, menggunakan buku refrensi, dan menulis.

\section{E. Keterkaitan Antara Media Puzzle Terhadap Kemampuan Anak dalam Mengenal Bentuk Geometri.}

Media puzzle dalam lingkup perkembangan yang terdapat tingkat pencapaian kemampuan mengenal konsep bentuk, ukuran, dan pola di indikator menyebutkan usia 4-5 tahun dapat mengenal tiga macam bentuk lingkaran, segitiga, dan persegi. Menyusun puzzle bentuk geometri ini dapat meningkatkan kognitif bagi anak. keterampilan kognitif (cognitive skill) berkaitan dengan kemampuan dalam belajar anak dan memecahkan masalah. Selain itu dapat meningkatkan keterampilan sosial bagi anak. Keterampilan sosial berkaitan dengan kemampuan berinteraksi dengan orang lain.

Untuk mengenal konsep bentuk geometri dengan adanya media puzzle anak dapat belajar secara cepat, karena dapat langsung menyusun bentuk di dalam papan yang sama bentuknya, selain itu anak dapat menyusun warna sesuai dengan urutannya. Maka dengan adanya media puzzle tersebut anak akan belajar mengenal bentuk geometri dengan benar

\section{SIMPULAN DAN SARAN}

\section{Kesimpulan}

Media puzzle dalam proses pembelajaran lebih bisa digunakan untuk pengenalan bentuk geometri anak dari pada pembelajaran tanpa media puzzle. Hal ini kerena penggunaan media puzzle dalam pembelajaran didukung oleh adanya warna-warni dalam setiap kepingan puzzle sehingga memungkinkan anak lebih menaruh perhatian dan menimbulkan kesan ketika proses pembelajaran. Sehingga anak lebih mudah mengingat apa yang dilihatnya. 


\section{Saran}

Bagi orang tua, hendaknya mengetahui karakteristik, cara untuk menstimulasi serta bahaya potensial anak usia 7-12 tahun. Agar anak dapat tumbuh dan berkembang sesuai dengan apa yang diharapkan orang tua. Bagi masyarakat, hendaknya memberikan contoh sikap positif terhadap anak yang berada di lingkungan sekitarnya.

\section{AKNOWLEDGMENT}

Peneleitian ini di dukung oleh UIN Sunan Ampel Surabaya.

\section{DAFTAR RUJUKAN}

Afifuddin, \& Beni. (2009). Metodologi Penelitian Kualitatif. Bandung: Pustaka Setia. Jatmika, Y. N. (2012). Ragam Aktivitas Harian Untuk Playgroup. Yogyakarta: Diva Press.

Kemendiknas. Sistem Pendidikan Nasional. , Pub. L. No. Nomor 20 Tahun 2003 (2003).

Natsir, M. (1999). Metode Penelitian. Jakarta: Galia Indonesia.

Sujiono, Y. N. (2004). Metode Pengembangan Kognitif. Jakarta: Universitas Terbuka.

\section{AUTHOR}

Ratna Pangatuti, merupakan Dosen Pendidikan Islam Anak Usia Dini UIN Sunan Ampel Surabaya dan aktif menulis diberbagai jurnal ilmiah 